\title{
Development of atrioventricular specialized tissue in human heart
}

\author{
Robert H. Anderson and Ian M. Taylor \\ From the Department of Anatomy, University of Manchester
}

The ontogenetic development of the atrioventricular specialized tissue has been studied in 9 hearts processed by paraffin-embedding techniques, and in 8 fresh hearts prepared by cryostat sectioning and processed using histological and neurohistochemical techniques. The results indicate that the atrioventricular node has a dual origin, derived in part from left sinus horn musculature and in part from atrioventricular canal musculature. This mode of development gives the node a trilaminar appearance. Other remnants of the atrioventricular canal musculature persist as ring bundles in the atrial margins of the atrioventricular orifices. The results also show that the specialized tissue is formed from a separate cellular population to the myocardium. This population differentiates in situ in the ventricular cavities to form the definitive AV specialized tissue. The results are compared and contrasted with previous investigations of the AV specialized tissue.

The embryological development of atrioventricular specialized tissue has been investigated by numerous workers, and several theories have been advanced regarding its origin and differentiation. Patten (1956) suggested that the atrioventricular node developed from sinus horn musculature, while Keith and Flack (1906) believed it to be formed from atrioventricular canal musculature. Two theories were also propounded to explain the differentiation of the ventricular specialized tissue. Tandler (1912), Shaner (1929), and Walls (1947) considered the tissue to be formed by active migration of the node, whereas Keith and Flack (I906), Mall (I912), and Calcagno (1941a, b) suggested it developed in situ in the ventricular subendocardium. In view of these discrepancies it was decided to reinvestigate the ontogenetic development of $A V$ specialized tissue. Since the earlier investigations were performed using histological sections prepared by embedding tissue in paraffin wax, we studied foetal specimens prepared by this technique. However, recent studies using animal material have shown that specialized tissue is more easily identified after use of neurohistochemical and histological techniques on cryostat prepared sections (Anderson, 1972a, b). Consequently we attempted to augment and expand the findings obtained using paraffin-embedded material by employing the cryostat method on fresh human foetal specimens. The present

Received 17 April 1972. report describes the results of this investigation.

\section{Materials and methods}

Both fresh human foetal specimens prepared for cryostat sectioning, and foetal specimens processed by the paraffin-embedding technique were studied in this investigation. The ages of the specimens studied and techniques employed with each foetus are indicated in Table $I$.

Parafin-embedded material Most of these specimens were already processed and in the histological collections of the University of Manchester or the Institute of Child Health, University of Liverpool. Some additional foetuses were processed by routine embedding in paraffin wax, sectioned at $8 \mu \mathrm{m}$ thickness and stained with either haematoxylin and eosin or Masson's trichrome technique.

Fresh material Human foetal specimens were obtained by abdominal hysterotomy. Blocks from the foetuses were immediately orientated on cryostat tissue holders and frozen in isopentane previously cooled in liquid nitrogen. The entire thorax was blocked in foetuses whose crown rump length was $90 \mathrm{~mm}$ or less. In larger specimens the heart was dissected out and so mounted as to allow sectioning of the cardiac septum in a coronal plane. The blocks were sectioned in a cryostat at Io-20 $\mu \mathrm{m}$ thickness. Alternate sections from the smaller hearts were mounted on separate glass slides. From the larger hearts 2 sections from each 5 cut were collected. In some of the hearts additional sections were collected on coverslips and stored for demonstration of catecholamines. 
The series on slides were processed to show either routine histology or cholinesterase activity.

Routine histology The sections were fixed in buffered formol-sucrose fixative (Karnovsky, 1964) for 5 minutes to 2 hours at room temperature. They were then stained using Masson's trichrome technique.

Cholinesterase activity The sections were fixed in buffered formol-sucrose fixative (Karnovsky, 1964) for up to 2 hours at $4^{\circ} \mathrm{C}$. They were then incubated in Gomori's medium (1952) at pH 6.0 using acetylthiocholine iodide as substrate. Incubation was allowed to proceed from 4 to 14 hours. The sections were then washed twice in distilled water, developed in fresh I per cent ammonium sulphide, counterstained for 30 seconds in haematoxylin, dehydrated, and mounted in balsam in tetrachlorethylene.

Demonstration of catecholamines The fluorescence technique of Spriggs et al. (1966) was employed. The sections were collected on coverslips and dehydrated in desiccators over phosphorus pentoxide for I to 2 hours. They were then heated at $80^{\circ} \mathrm{C}$ for I $\frac{1}{4}$ hours with $5 \mathrm{~g}$ paraformaldehyde previously stored at 70.4 per cent relative humidity. After mounting in liquid paraffin the sections were viewed in a Zeiss photomicroscope using an ultraviolet source, excitor filter $B \mathrm{BG}_{4} / \mathrm{I} \mathrm{mm}$ and barrier filter GG $2 / \mathrm{I} \mathrm{mm}$.

\section{Results}

7-II.5 $\mathrm{mm}$ specimens The right atrial wall in the region of the coronary sinus ostium shows a thickening composed of multiple small cells. The atrial wall is continuous with the musculature of the atrioventricular canal which is composed of large cells. These cells in turn communicate with a distinct layer of cells occupying the subendocardial regions of
TABLE Specimens studied

\begin{tabular}{|c|c|c|}
\hline $\begin{array}{l}\text { Length of } \\
\text { specimen } \\
(C / R)\end{array}$ & $\begin{array}{l}\text { Fresh or } \\
\text { paraffin- } \\
\text { embedded }\end{array}$ & Source and techniques employed \\
\hline $7 \mathrm{~mm}$ & Paraffin & $\mathrm{H}_{7}$ - University of Manchester collection \\
\hline $9 \mathrm{~mm}$ & Paraffin & H9 - University of Manchester collection \\
\hline II. $5 \mathrm{~mm}$ & Paraffin & HI I. 5 - University of Manchester collection \\
\hline $15 \mathrm{~mm}$ & Paraffin & HI5 - University of Manchester collection \\
\hline I5 mm & Paraffin & Hi5A - University of Manchester collection \\
\hline $20 \mathrm{~mm}$ & Paraffin & Hr49 - Institute of Child Health, University of Liverpool \\
\hline $24 \mathrm{~mm}$ & Paraffin & $\mathrm{H}_{24}$ - University of Manchester collection \\
\hline $28 \mathrm{~mm}$ & Fresh & Histology and cholinesterases \\
\hline $29 \mathrm{~mm}$ & Paraffin & - Institute of Child Health, University of Liverpool \\
\hline $37 \mathrm{~mm}$ & Paraffin & - Institute of Child Health, University of Liverpool \\
\hline $46 \mathrm{~mm}$ & Fresh & Histology, cholinesterases, catecholamines \\
\hline $85 \mathrm{~mm}$ & Fresh & Histology, cholinesterases \\
\hline $90 \mathrm{~mm}$ & Fresh & Histology, cholinesterases, catecholamines \\
\hline $100 \mathrm{~mm}$ & Fresh & Histology, cholinesterases \\
\hline I IO $\mathrm{mm}$ & Fresh & Histology, cholinesterases \\
\hline $120 \mathrm{~mm}$ & Fresh & Histology, cholinesterases \\
\hline $190 \mathrm{~mm}$ & Fresh & Histology, cholinesterases, catecholamines \\
\hline
\end{tabular}

The same abbreviations are used throughout the illustrations and are as follows:-

AVB Atrioventricular bundle

AVCM Atrioventricular canal musculature

AVCP Atrioventricular canal musculature portion of $A V$ node

AM Atrial myocardium

AVR Atrioventricular ring of fibrous tissue

CS Coronary sinus

IAS Interatrial septum

IP Intermediate portion of $A V$ node

IVS Interventricular septum

$L B B \quad$ Left bundle-branch of $A V$ bundle

$R A \quad$ Cavity of right atrium

SEST Subendocardial specialized tissue

SHM Sinus horn musculature

SHP Sinus horn musculature portion of $A V$ node

SI Septum intermedium

ST Specialized tissue

VM Ventricular myocardium

FIG. I $7 \mathrm{~mm}$ embryo. Coronal section through posterior regions of heart. The specialized tissue is discrete from the myocardium, and is divisible into portions related to the sinus horn, $A V$ canal, and ventricular endocardium. (Haematoxylin and eosin.) Paraffin prepared material.

FIG. 2 II mm embryo. Coronal section of the posterior part of the interventricular septum. The AV bundle is clearly visible astride the muscular septum. (Haematoxylin and eosin.) Paraffin prepared material.

FIG. $320 \mathrm{~mm}$ embryo. Oblique section of the septal aspect of the right atrioventricular ring. Specialized cells are seen related to the coronary sinus, and in the fibrous tissues of the ring.

The vertical bars are artefactual. Trichrome stain. Paraffin prepared material.

FIG. $437 \mathrm{~mm}$ embryo. Section in same position as Fig. 2. The specialized tissues are better differentiated and are similar in cell size to the ventricular myocardium. (Haematoxylin and eosin.) Paraffin prepared material.

FIG. $528 \mathrm{~mm}$ embryo. Section is similar in position to Fig. 3. The sinus horn musculature is innervated with ChE positive fibres. The AV bundle is uninnervated but the individual cells are ChE positive. Cryostat material. Cholinesterase preparation.

FIG. $626 \mathrm{~mm}$ embryo. High power of adjacent section to Fig. 5 showing the AV bundle. The cells are similar in size to the ventricular myocardium. Cryostat material. Trichrome stain. 

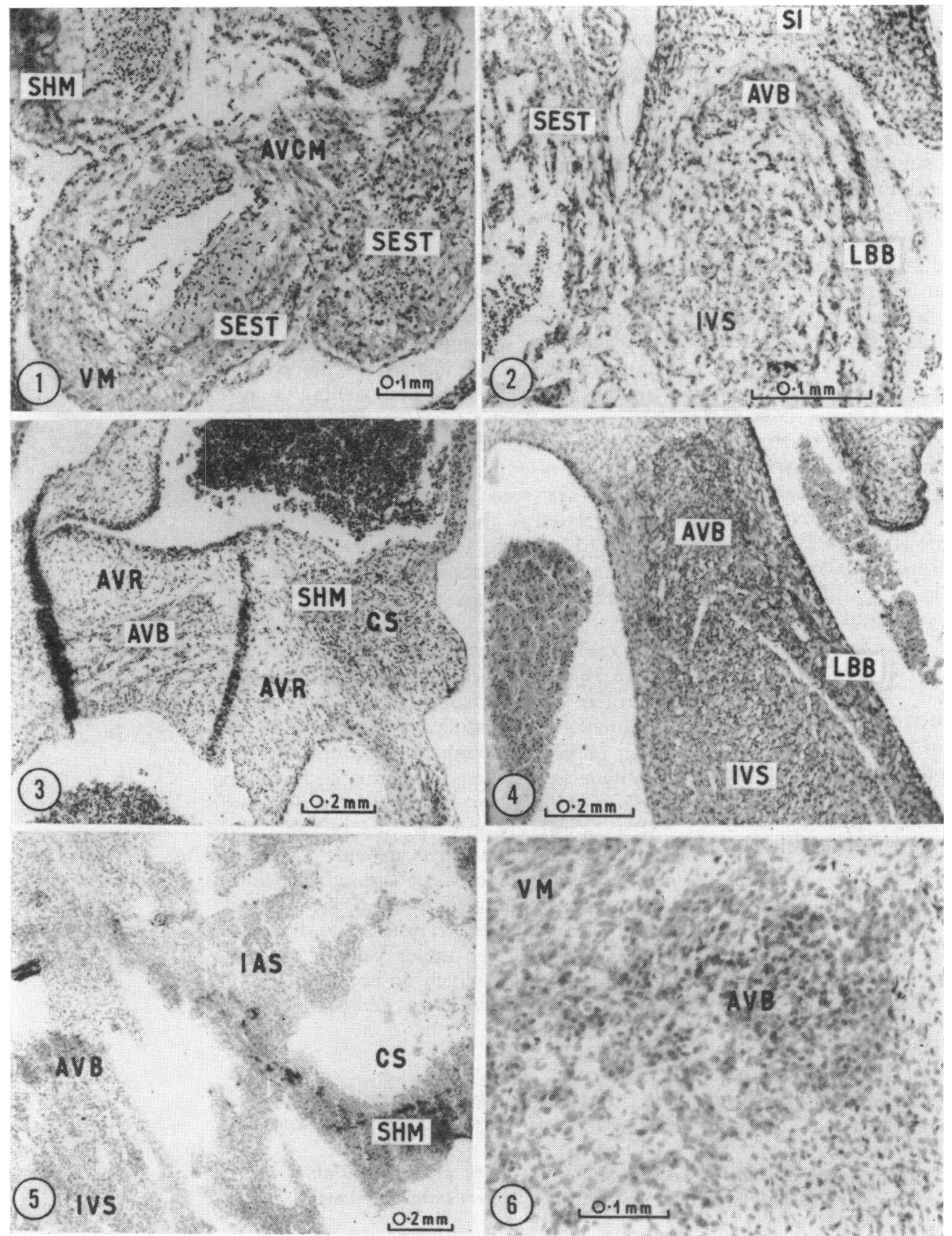

Plate I 
the ventricles. These cells are appreciably larger than the cells forming the ventricular walls, and extend throughout the ventricular cavities (Fig. I).

$15 \mathrm{~mm}$ specimens The ventricular septum is joining with the septum intermedium in these specimens. A distinct crescent of cells is discernible astride the muscular septum communicating with the canal musculature posteriorly and the subendocardial layer inferiorly. This subendocardial layer is still distinct from the ventricular walls, though the cells in the two layers are similar in size (Fig. 2). The musculature forming the atrial margin of the septum intermedium is loosely arranged, and it is not possible to identify any structure resembling the atrioventricular node.

$20 \mathrm{~mm}$ specimen The fibrous tissue of the atrioventricular ring is formed in this specimen. The atrioventricular bundle can be identified passing through this tissue, and can be traced towards the ostium of the coronary sinus. In this area the atrial wall is thickened and composed of multiple small cells (Fig. 3). However, it is difficult to differentiate the subendocardial network from the ventricular myocardium.

$28 \mathrm{~mm}$ specimen This was the earliest fresh specimen studied. The atrioventricular bundle is well formed astride the interventricular septum, and its cells are cholinesterase (ChE) positive (Fig. 5 and 6 ). The proximal bundle-branches are also distinguishable by their $\mathrm{ChE}$ activity. Their constituent cells are similar in size to the cells of the ventricles. A circumferential ring of $\mathrm{ChE}$ positive cells can also be identified around the atrial margin of the right $\mathrm{AV}$ ring.

A multicellular knot of tissue containing cholinesterase positive nerves is found in the region of the coronary sinus. In contrast, $\mathrm{ChE}$ positive nerves are absent from the remaining atrial tissues (Fig. 5 and 6).

$37 \mathrm{~mm}$ specimen Examination of this paraffin-embedded specimen shows a similar picture to that seen in the $28 \mathrm{~mm}$ specimen. The AV bundle is well formed, and the proximal bundle-branches are composed of cells similar in size to the ventricular myocardial cells (Fig. 4). Examination of the interatrial septum reveals no evidence of an AV nodelike structure.

$46 \mathrm{~mm}$ specimen The AV bundle and branches are well formed and easily recognized by their ChE content. In the area of the AV node the previously noted multicellular, innervated area in relation to the coronary sinus is now seen to be encroaching upon the upper end of the $\mathrm{ChE}$ positive $\mathrm{AV}$ bundle (Fig. 7 and 8). This is the first indication of a structure resembling the adult AV node. The nerves are seen predominantly among the cells related to the coronary sinus, though a few $\mathrm{ChE}$ positive nerves are also found in the atrial tissues. Sections processed for catecholamines are negative in this heart.

85-120 $\mathrm{mm}$ specimens These specimens reveal a more or less similar stage in development of the specialized tissue. The bundlebranches are recognizable by their ChE content (Fig. 9), though they do not appear to contain any nervous elements, and examination of the adjacent histological section shows that the cells are now slightly larger than those of the ventricular myocardium. The upper end of the bundle passes through the fibrous ring and runs into the atrial tissues (Fig. Io14). It is recognizable in this situation by its $\mathrm{ChE}$ content. The upper cells of the atrioventricular node which do not stain for ChE activity but do contain nerves overlie the

FIG. $746 \mathrm{~mm}$ embryo. Section in similar plane to Fig. 3 and 5. The specialized tissue is divisible into sinus horn, AV canal, and endocardial portions. Cryostat material. (Trichrome stain.)

FIG. $846 \mathrm{~mm}$ embryo. Section from same series as Fig. 7 showing the approximation of the sinus and $A V$ canal portions of the atrioventricular node with an intervening intermediate portion. Cryostat material. (Trichrome stain.)

FIG. $990 \mathrm{~mm}$ embryo. Section in similar plane to Fig. 7. The ChE positive AV bundle and ChE + innervated sinus portions are clearly seen. Cryostat material. Cholinesterase preparation. FIG. IO $120 \mathrm{~mm}$ embryo. This section is the most anterior of a series continued in Fig. II-I4. The plane of sectioning is coronal to the septum, and the sections are viewed from behind, so that the right side of the septum is to the right. This section is through the anterior portion of the node, and the upward extension of the AV bundle is clearly discrete from the remainder of the node. Cryostat material. (Trichrome stain.) 

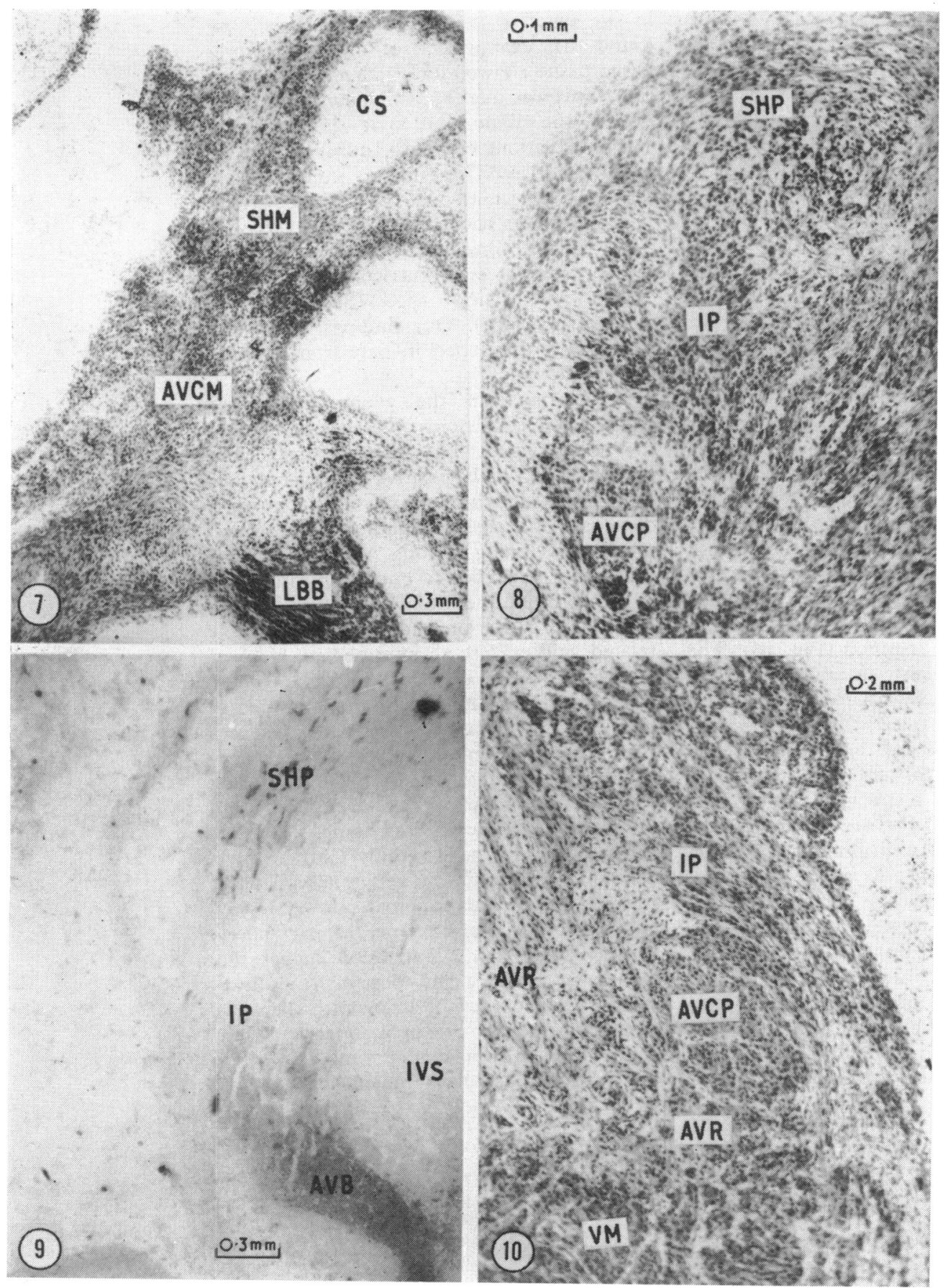

Plate 2

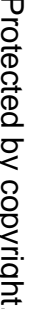


bundle as it pierces the ring and thus produce a trilaminar appearance. The intermediate layer is composed of multiple small cells, whereas the atrial layer is composed of circumferential pale staining cells. The trilaminar arrangement persists posteriorly, the $\mathrm{ChE}$ positive bundle running the length of the node (Fig. I3 and I4) and continuing into the atrial margin of the right AV orifice. The upper posterior portion of the atrial node is well innervated, as are the pale staining transitional cells seen in the region of the coronary sinus. In addition to the $\mathrm{ChE}$ positive ring seen in the right $\mathrm{AV}$ ring, a well innervated circumferential ring of $\mathrm{ChE}$ positive tissue is identified in the atrial margin of the left AV ring, particularly in the region of aorticmitral valve continuity. Though catecholamine-containing nerve trunks are identified in the pericardium and alongside the coronary vessels, no CA-containing nerves are identified in relation to the specialized tissue.

$190 \mathrm{~mm}$ specimen This was the oldest fresh specimen studied, and though the AV bundle and branches are intensely $\mathrm{ChE}$ positive, activity is confined to the cells and no $\mathrm{ChE}$ positive nerves are identified (Fig. I6). The AV node is now similar to its adult form (Fig. I5 and 16). The backward extension of the bundle can again be traced through the node into the atrial margin of the tricuspid ring. It is recognizable in this situation by both its $\mathrm{ChE}$ content and its histological appearance. The node has a distinct trilaminar appearance (Fig. 15 and 16). The well-innervated portion of the node is situated posteriorly in relation to the coronary sinus. The tricuspid ring of $\mathrm{ChE}$ positive tissue is well formed laterally and is also innervated by $\mathrm{ChE}$ positive fibres (Fig. 17 and 18). When traced posteriorly it is found to be continuous with the backward extension of the nodal bundle. Catecholaminecontaining nerves are not identified in relation to the specialized tissue at this stage.

\section{Discussion}

We were able to distinguish specialized tissue in the paraffin wax prepared material, but found that examination of the freshly prepared tissue allowed for much easier recognition. This was due to the cholinesterase reaction of the tissue, and to its association in certain situations with large numbers of $\mathrm{ChE}$ positive nerves. These factors indicated that the atrioventricular node was of dual origin. Earlier workers have suggested that the node is of either left sinus horn origin (Patten, 1956; James, 1970) or atrioventricular canal origin (Keith and Flack, 1906; Shaner, 1929; Lieberman, I970). Our findings show that the node is developed in part from each of these structures.

In hearts from the youngest embryos studied two collections of tissue are seen in the nodal region. The more proximal is a multicellular, $\mathrm{ChE}$ positive innervated collection related to the coronary sinus. The more distal is a $\mathrm{ChE}$ positive bundle of cells related to the developing fibrous AV septum, and continuous with the AV bundle. Examination of subsequent specimens shows that these specialized collections become more closely related, and enclose an intermediate block of specialized tissue to form the node. In the oldest specimens studied the node is seen to have a trilaminar appearance. At this stage a $\mathrm{ChE}$ positive column of cells is clearly recognized on the atrial side of the fibrous ring continuous distally with the AV bundle and proximally with the AV ring tissue. The intermediate nodal zone is weakly ChE positive, but contains few $\mathrm{ChE}$ positive nerves, while the circumferential proximal portion is well supplied by $\mathrm{ChE}$ positive nerves, particularly in its posterior part. We therefore suggest that the lower bundle, and possibly the intermediate portion, are of atrioventricular canal origin, whereas the proximal, innervated, portion is derived from the left sinus horn. This concept of nodal development satisfies both

FIG. II-I4 Same series as Fig. Io. All cryostat material.

FIG. II Section through the middle of the node showing the trilaminar appearance. (Trichrome stain.)

FIG. I2 Adjacent section to Fig. II processed for cholinesterase. The ChE positive bundle is seen, with the intermediate portion above it. Few ChE positive nerves are present in the sinus portion.

FIG. I3 Section of posterior node. A prominent artery is seen and the trilaminar appearance is still present. (Trichrome stain.)

FIG. I4 Adjacent section to Fig. 13. The nodal bundle is intensely ChE positive, while the posterior part of the sinus portion is well supplied with ChE + nerves. Cholinesterase preparation. 


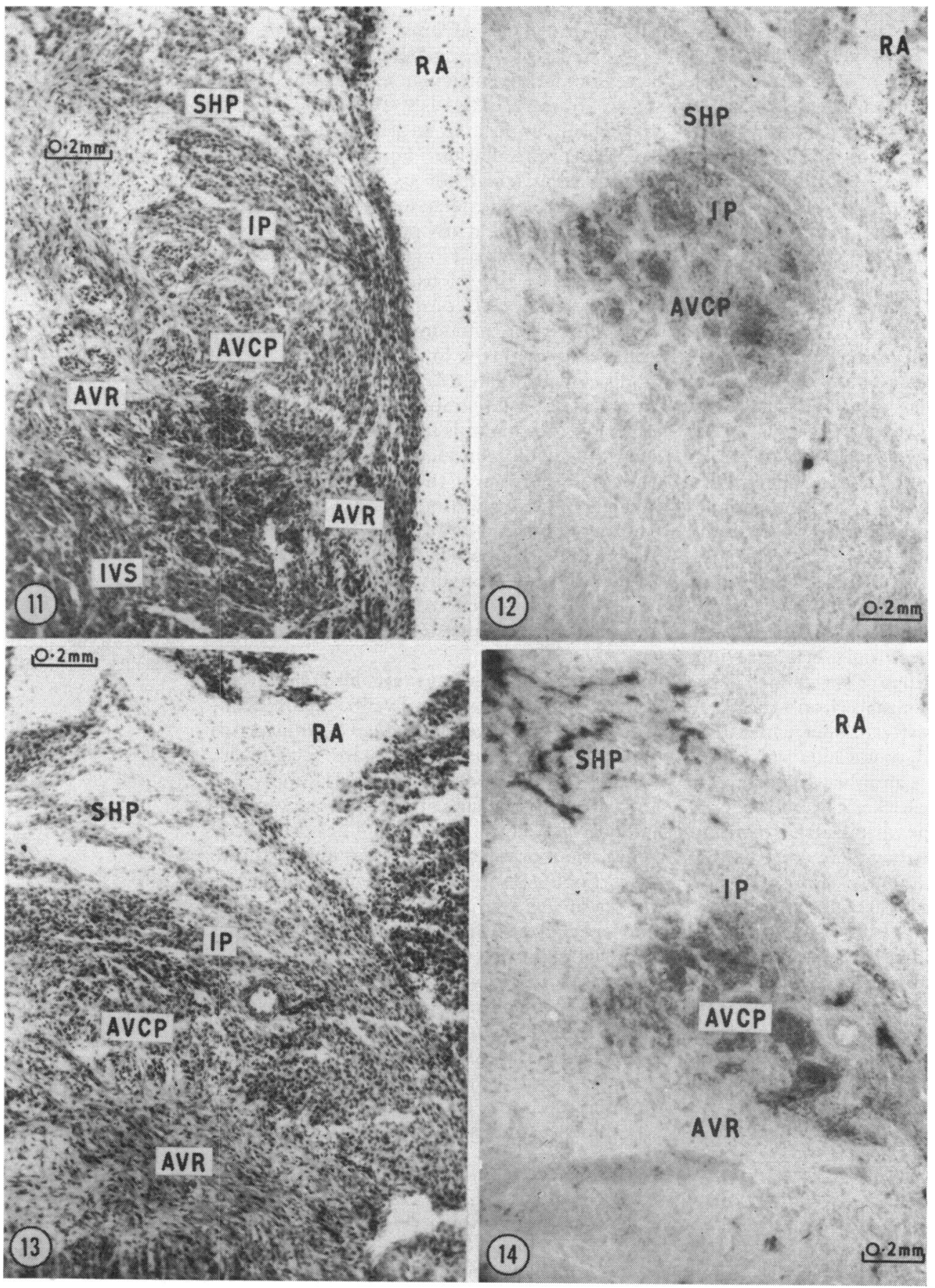

Plate 3 
the evidence provided by James (1970) to support migration of sinus musculature, and the physiological findings of Lieberman (1970) which indicate that the node is of atrioventricular canal origin. It is also endorsed by the reported arrangement of specialized tissue in a human heart exhibiting laevo-transposition with dextro-bulboventricular loop (anatomically corrected transposition) (Anderson, Arnold, and Jones, 1972). Furthermore, the trilaminar arrangement of the node as presently reported substantiates the findings of Anderson and Latham (I97I) in neonatal hearts. This nodal disposition is unlike that described by Tawara (1906), but is similar to that observed in the human heart by Truex and Smythe (1965) and in the rabbit heart by both electrophysiologists (Paes de Carvalho, 196I) and morphologists (DeFelice and Challice, 1969; Anderson, 1972a).

The disposition of specialized tissue as presently reported in the atrial margins of the atrioventricular orifices resembles the arrangement reported in lower animals (Keith and Mackenzie, 1910) and birds (Davies, 1930). It is very similar to recent findings in the hearts of adult guinea-pigs, rats, and rabbits (Anderson, $1972 b$ and Anderson, unpublished observations). There has been only brief previous mention of complete rings of specialized tissue in such positions in mammals (Robb and Petri, 196I), but several investigators have identified extranodal specialized tissue adjacent to the atrioventricular fibrous annulus. In particular, Kent (1893, I914) illustrated several knots of specialized cells in the distal atrial margins, but did not indicate if they were connected in annular formation. Similarly, Truex and his co-workers (Truex and Bishof, 1958; Truex, Bishof, and Hoffman, 1958; Truex, Bishof, and Downing, I960) identified extensive atrial 'left-over tissue' in human foetal and neonatal hearts, again without referral to any ring formation. These workers also found that such tissue was less easily recognizable in older hearts, and it is likely that these previously described knots are well-formed segments of a more extensive annulus of specialized tissue such as presently described, but that neurohistochemical or other special techniques are necessary to reveal its full extent.

The previously defined segments of ring tissue have frequently been shown to effect accessory atrioventricular connexions (Kent, 1893; Truex et al., 1958, 1960) and as such have been implicated in production of ventricular pre-excitation. Faulty formation of the atrioventricular fibrous ring would clearly allow such connexions to be made through specialized tissue at any point round the atrioventricular orifices. However, the presence of this complete ring of tissue which is well innervated and $\mathrm{ChE}$ positive suggests that it may fulfil other functions. The ring is directly continuous with the lower portion of the AV node, and through this with the AV bundle. Since atrial cells impinge on the superior aspect of the ring, it is feasible that the specialized cells could conduct the sinus impulse to the lower portion of the node, thus avoiding the upper and middle portions of the node, and possibly functioning as a bypass tract. It may also be of significance that while the ring tissue was easily recognizable, we were unable to identify any specialized tissue in the regions designated by James (1963) as 'internodal tracts'.

The present findings are also significant with regard to the origin of ventricular specialized tissue. At the earliest stage examined two distinct cellular populations are recognized. One of these is specialized and is subdivided into atrioventricular canal tissue and a subendocardial layer of cells. The other cell population forms the ventricular myocardium. This finding is in close agreement with the theory of DeHaan (I96I) that the myocardial and specialized cells are formed by separate cellular migrations from the myoepicardial mantle. Thus a layer of specialized cells is present throughout the ventricular cavities, and examination of hearts from older specimens shows that the cells in part differentiate into the ventricular specialized tissue. Our findings therefore indicate that the tissue is developed in situ as previously suggested by

FIG. I5 $190 \mathrm{~mm}$ embryo. Coronal section through $A V$ node showing trilaminar appearance (Trichrome stain.) Cryostat material.

FIG. I6 Section anterior to Fig. I5 showing conspicuous differences in ChE reaction of nodal portions. Cholinesterase preparation. Cryostat material.

FIG. I7 $190 \mathrm{~mm}$ embryo. This is a coronal section through the lateral aspect of the tricuspid ring. $A$ well-marked bundle of specialized tissue is present in the atrial margin of the ring. (Trichrome stain.)

FIG. I8 Adjacent section to Fig. I7. Note that the specialized tissue is intensely ChE positive, and the immediately surrounding myocardium is well innervated. Cholinesterase preparation. 

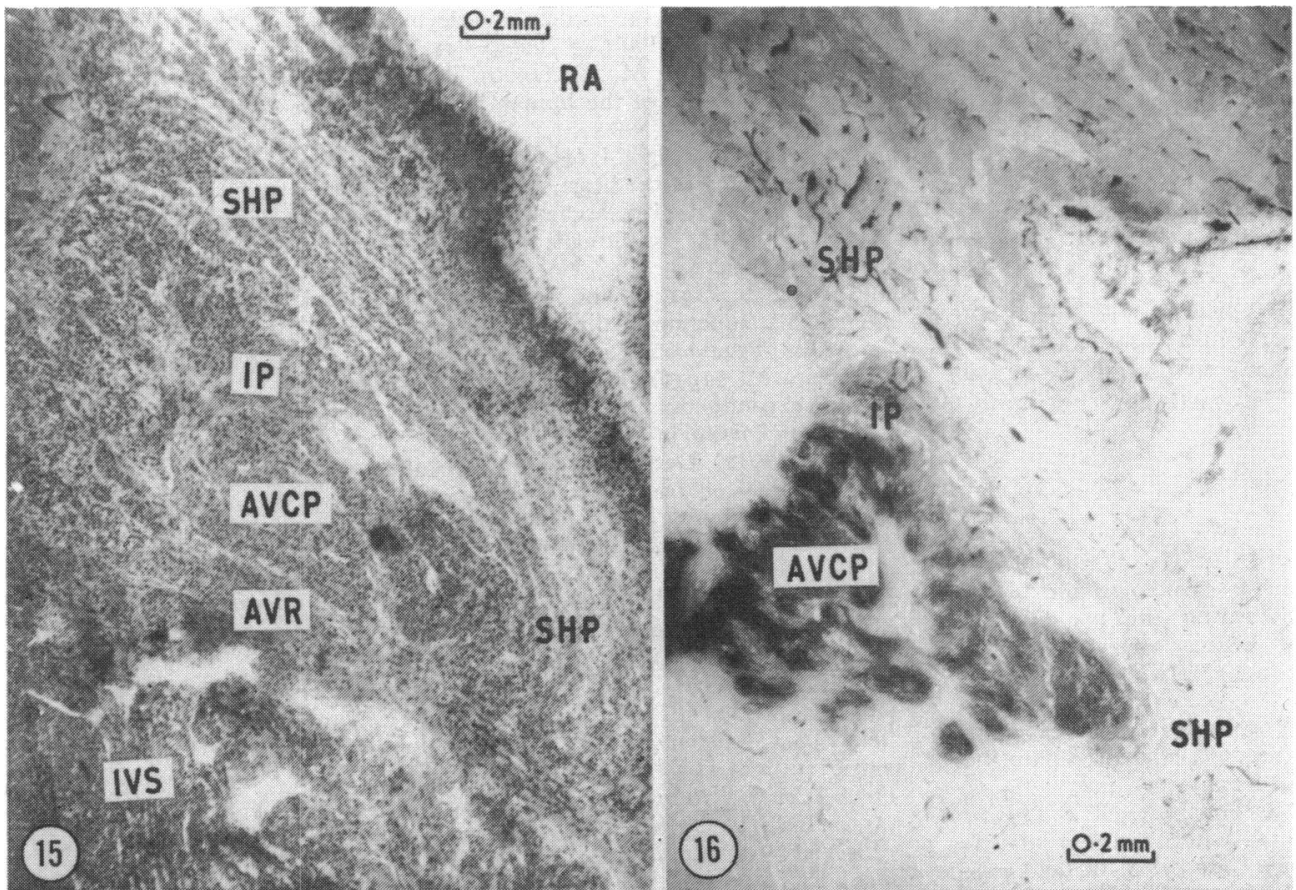

\section{(16)}

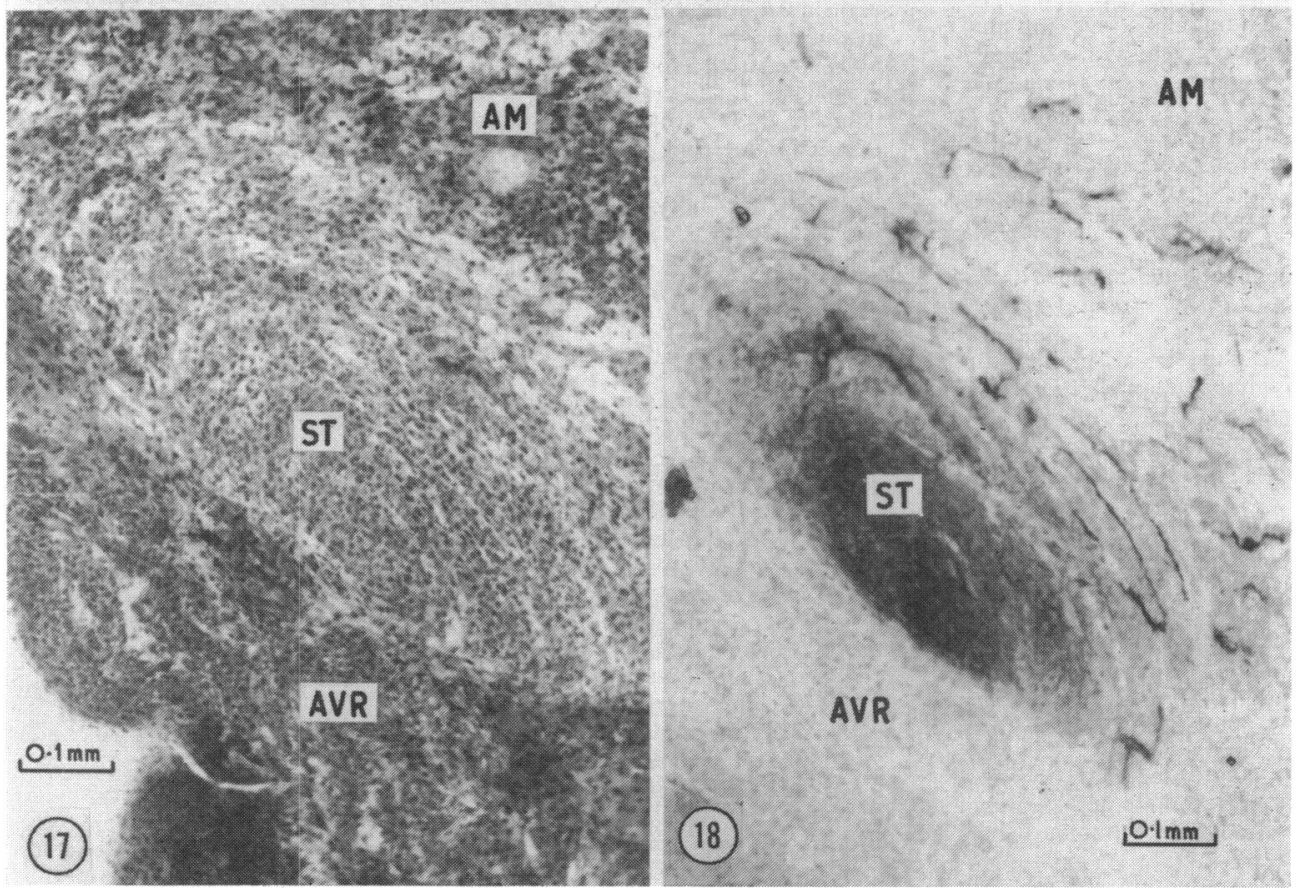

Plate 4

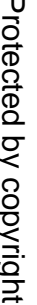


Keith and Flack (I906), Mall (I9I2), and Calcagno (I94Ia, b).

Additional evidence to support this concept of development has been supplied by examination of clinical and pathological material (James and Konde, 1969; James, 1970; Anderson, Jones, and Arnold, I97I).

The authors wish to thank Professor G. A. G. Mitchell for his help and encouragement; Dr. J. A. Gosling for his valued criticisms; Dr. G. T. Ashley, University of Manchester, and Dr. R. S. Jones and the Institute of Child Health, University of Liverpool, for access to their histological collections; and Mr. P. Howarth for the photomicrographs.

\section{References}

Anderson, R. H. (1972a). The histologic and histochemical evidence concerning the presence of morphologically distinct cellular zones within the rabbit atrioventricular node. Anatomical Record, I43, 7.

Anderson, R. H. (1972b). The disposition, morphology and innervation of cardiac specialised tissue in the guinea pig. Fournal of Anatomy, 111453.

Anderson, R. H., Arnold, R., and Jones, R. S. (1972). L-transposition associated with D-bulboventricular loop in situs inversus. Circulation. In the press.

Anderson, R. H., Jones, R. S., and Arnold, R. (197I). Observations on the conducting tissue in congenitally malformed human hearts with reference to its embryological development. Fournal of Anatomy, 110, 150 (P).

Anderson, R. H., and Latham, R. A. (1971). The cellular architecture of the human atrioventricular node, with a note on its morphology in the presence of a left superior vena cava. Fournal of Anatomy, rog, 443 .

Calcagno, I. R. (194Ia). Desarrollo del haz de His en embriones vacunos. Revista de la Sociedad Argentina de Biologia, 17, 213.

Calcagno, I. R. (I94Ib). Desarrollo del nódulo de Tawara en embriones vacunos. Revista de la Sociedad Argentina de Biología, 17, 221.

Davies, F. (1930). The conducting system of the bird's heart. Fournal of Anatomy, 64, 129.

DeFelice, L. J., and Challice, C. E. (1969). Anatomical and ultrastructural study of the electrophysiological atrioventricular node of the rabbit. Circulation Research, 24, 457.

DeHaan, R. L. (I96I). Differentiation of the atrioventricular conducting system of the heart. Circulation, $24,458$.

Gomori, G. (1952). Microscopic Histochemistry - Principles and Practise. University of Chicago Press, Chicago.

James, T. N. (1963). The connecting pathways between the sinus node and $A-V$ node and between the right and the left atrium in the human heart. American Heart fournal, 66, 498.

James, T. N. (1970). Cardiac conduction system: fetal and postnatal development. American fournal of Cardiology, 25, 213.

James, T. N., and Konde, W. N. (1969). A clinicopathologic study of heart block in a dog, with remarks pertinent to the embryology of the cardiac conduction system. American fournal of Cardiology, 24, 59.

Karnovsky, M. J. (1964). The localization of cholinesterase activity in rat cardiac muscle by electron microscopy. Fournal of Cell Biology, 23, 217.

Keith, A., and Flack, M. W. (1906). The auriculoventricular bundle of the human heart. Lancet, 2 , 359.

Keith, A., and Mackenzie, I. (I9I0). Recent researches on the anatomy of the heart. Lancet, $\mathbf{r}$, ror.

Kent, A. F. S. (1893). Researches on the structure and function of the mammalian heart. Fournal of Physiology, 14, 233.

Kent, A. F. S. (I914). The right lateral auriculoventricular junction of the heart. Fournal of Physiology, 48, Proceedings, pp. xxii, lvii, lxiii.

Lieberman, M. (1970). Physiologic development of impulse conduction in embryonic cardiac tissue. American fournal of Cardiology, 25, 279.

Mall, F. P. (1912). On the development of the human heart. American fournal of Anatomy, 13, 249.

Paes de Carvalho, A. (196I). Cellular electrophysiology of the atrial specialized tissues. In The Specialised Tissues of the Heart, p. II5. Ed. by A. Paes de Carvalho, W. C. de Mello, and B. F. Hoffman. Elsevier, Amsterdam.

Patten, B. M. (1956). The development of the sinoventricular conduction system. University of Michigan Medical Bulletin, 22, I.

Robb, J. S., and Petri, R. (196I). Expansions of the atrioventricular system in the atria. In The Specialised Tissues of the Heart, p. I. Ed. by A. Paes de Carvalho, W. C. de Mello, and B. F. Hoffman. Elsevier, Amsterdam.

Shaner, R. F. (1929). The development of the atrioventricular node, bundle of His, and sinuatrial node in the calf, with a description of a third embryonic node-like structure. Anatomical Record, 44, 85.

Spriggs, T. L. B., Lever, J. D., Rees, P. M., and Graham, J. P. D. (I966). Controlled formaldehydecatecholamine condensation in cryostat sections to show adrenergic nerves by fluorescence. Stain Technology, 41, 323.

Tandler, J. (1912). In Manual of Human Embryology, Vol. 2, p. 569. Ed. by F. Keibel and F. P. Mall. J. B. Lippincott, Philadelphia and London.

Tawara, S. (1906). Das reizleitungssystem des saugetierherzens. Fischer, Jena.

Truex, R. C., and Bishof, J. K. (I958). Conduction system in human hearts with interventricular septal defects. Fournal of Thoracic Surgery, 35, $42 \mathrm{I}$.

Truex, R. C., Bishof, J. K., and Downing, D. F. (1960). Accessory atrioventricular muscle bundles. II. Cardiac conduction system in a human specimen with Wolff-Parkinson-White syndrome. Anatomical Record, 137, 417.

Truex, R. C., Bishof, J. K., and Hoffman, E. L. (I958). Accessory atrioventricular muscle bundles of the developing human heart. Anatomical Record, r31, 45.

Truex, R. C., and Smythe, M. Q. (1965). Recent observations on the human cardiac conduction system, with special considerations of the atrioventricular node and bundle. In Electrophysiology of the Heart, p. 177. Ed. by B. Taccardi and G. Marchetti. Pergamon Press, Oxford.

Walls, E. W. (1947). The development of the specialized conducting tissue of the human heart. fournal of Anatomy, 81, 93.

Requests for reprints to Dr. R. H. Anderson, Department of Anatomy, University of Manchester, Manchester MI3 9PL. 